\title{
Preliminarno izvješće o arheološkim istraživanjima lokaliteta Stari grad Ljubuški
}

\author{
Nina Čuluak \\ Sveučilište u Mostaru, Filozofski fakultet \\ University of Mostar \\ Faculty of Humanities and Social \\ Sciences \\ E-mail: nina.culjak@ff.sum.ba \\ ANTE UGLEŠlĆ \\ Sveučilište u Zadru, Odjel za arheologiju \\ University of Zadar, Department of \\ Archaeology \\ E-mail: auglesic@unizd.hr
}

UDK: 903/904(497.6 Ljubuški)

Prethodno priopćenje

Primljeno: 18. travnja 2021.

Prihvaćeno: 29. lipnja 2021.

\section{Sažetak}

U članku se donose rezultati arheoloških istraživanja provedenih na lokalitetu Stari grad Ljubuški, u Ljubuškom. Ta su istraživanja bila od velikog značenja jer je riječ o prvim arheološkim iskopavanjima toga znamenitoga hercegovačkog spomenika u narodu najčešće zvana "Kula hercega Stjepana". Nakon arheoloških istraživanja uslijedili su konzervatorsko-restauratorski radovi kojima će utvrda biti spašena od urušavanja, jer su pojedini dijelovi njezinih bedema i drugih konstruktivnih elemenata bili doslovce pred urušavanjem ili su već urušeni. Arheološka istraživanja koja je proveo Studij arheologije Filozofskog fakulteta Sveučilišta u Mostaru, iznjedrila su pregršt zanimljivih podataka i niz pokretnih arheoloških nalaza koji će u budućnosti biti izloženi u muzejskoj zbirci planiranoj u sklopu utvrde i dostupni široj javnosti. Sve navedene aktivnosti vezane uz arheološka istraživanja i konzervatorsko-restauratorske radove organizirane su u okviru dva EU projekta prekograničnih suradnji: FORT-NET i Heritage 
Nina Čuljak - Ante Uglešić - Preliminarno izvješće o arheološkim istraživanjima...

REVIVED. U ovom radu prvi put objavljujemo rezultate provedenih arheoloških istraživanja.

Ključne riječi: Hercegovina; srednji vijek; srednjovjekovni gradovi; herceg Stjepan Kosača; Stari grad Ljubuški.

\title{
Preliminary report on the archaeological research of the site Stari grad Ljubuški
}

\author{
Preliminary communication \\ Received: 18 April 2021 \\ Accepted: 29 June 2021
}

\section{Summary}

The paper shows results of the archaeological research conducted at the site Stari grad Ljubuški, in Ljubuški. Those excavations were of great significance because they were the first archaeological excavations of that remarkable Herzegovinian monument known among the people as "Kula hercega Stjepana". Conservation and restoration work followed the archaeological excavations. They will save the fortress from the collapse, since some parts of its walls and other constructive elements were almost destroyed or already collapsed. Archaeological research conducted by the Department of Archaeology, Faculty of Humanities and Social Sciences, University of Mostar, came up with many interesting data and numerous movable archaeological finds that will be displayed in the museum collection planned within the fortress and available to the general public. All the mentioned activities related to archaeological research and conservation and restoration work were organized in the framework of two EU cross-border cooperation projects: FORT-NET and Heritage REVIVED. The results of the conducted archaeological research will be published for the first time in this paper.

Keywords: Herzegovina: Middle Ages; medieval towns; Duke Stjepan Kosača; Stari grad Ljubuški. 


\section{Uvod}

Arheološka istraživanja lokaliteta Stari grad Ljubuški provedena su kroz dvije istraživačke kampanje, tijekom 2020. i 2021. godine. Obje kampanje financirane su u okviru europskih projekata prekogranične suradnje, ${ }^{1}$ pri čemu je Studij arheologije Filozofskog fakulteta Sveučilišta u Mostaru bio podizvođač zadužen za provedbu arheoloških iskopavanja. ${ }^{2}$ Lokalitet Stari grad Ljubuški (sl. 1), u narodu najčešće zvan "Kula Herceg Stjepana", ${ }^{3}$ poznat je iz povijesnih izvora, a obrađivan je višestruko i u znanstvenoj literaturi. Njegova sačuvanost kao kulturno-povijesnog spomenika (grada-utvrde) bila je izuzetna sve do razornog potresa 1962. godine. Epicentar toga potresa bio je u Makarskom primorju, ali s obzirom na jačinu, znatno se osjetio i u Ljubuškom gdje su najveća urušavanja bila upravo na prostoru Staroga grada i oko njega. Tada su porušeni znatni dijelovi bedema, a najviše je stradala središnja kula.

1 Istraživanja 2020. godine provedena su u sklopu projekta FORT-NET iz okvira Programa prekogranične suradnje Bosna i Hercegovina - Crna Gora koji financira Europska unija, a implementiraju ga Grad Ljubuški kao nositelj projekta, Javna ustanova Razvojna agencija Županije zapadnohercegovačke HERAG, Centar za inicijative iz oblasti održiva turizma (CSTI) i Nacionalna turistička organizacija Crne Gore (NTO). Istraživanja 2021. godine bila su u sklopu projekta Heritage REVIVED iz okvira Programa prekogranične suradnje Hrvatska - Bosna i Hercegovina - Crna Gora, koji financira Europska unija, a implementiraju ga Grad Ljubuški kao nositelj projekta, Javna Ustanova Razvojna agencija Zupanije zapadno-hercegovačke - HERAG i partneri iz Republike Hrvatske (Grad Solin i Županijska uprava za ceste Split) i Crne Gore (Općina Ulcinj).

2 Voditeljica arheoloških istraživanja u obje kampanje bila je doc. dr. sc. Nina Čuljak (Filozofski fakultet Sveučilišta u Mostaru). Osim voditeljice, članovi stručnog istraživačkog tima bili su: prof. dr. sc. Ante Uglešić i izv. prof. dr. sc. Dario Vujević (Odjel za arheologiju Sveučilišta u Zadru i vanjski suradnici Sveučilišta u Mostaru), doc. dr. sc. Edita Vučić (Sveučilište u Mostaru), v. asist. Mirko Rašić (vanjski suradnik Sveučilišta u Mostaru), v. asist. Tino Tomas (Sveučilište u Mostaru) te Marina Boban, mag. arch. (Općina Ljubuški) i Stipan Dilber, mag. arch. (Franjevački muzej "Fra Jozo Križić" Tomislavgrad). U istraživanjima su (u drugoj kampanji) sudjelovali i studenti Studija arheologije Filozofskog fakulteta Sveučilišta u Mostaru koji su tamo imali priliku odraditi svoju studentsku terensku nastavu/praksu pod vodstvom izv. prof. dr. sc. Darija Vujevića. Istraživanja su organizirana tijekom 14 radnih dana (prva kampanja), odnosno u 13 radnih dana (druga kampanja).

3 Pri spomenu toga lokaliteta dodatno se izdvaja glavnu kulu kao "Hercegušu", dok se pod "Kula herceg Stjepana" često misli na cijeli lokalitet Stari grad Ljubuški. 
Nina Čuljak - Ante Uglešić - Preliminarno izvješće o arheološkim istraživanjima...

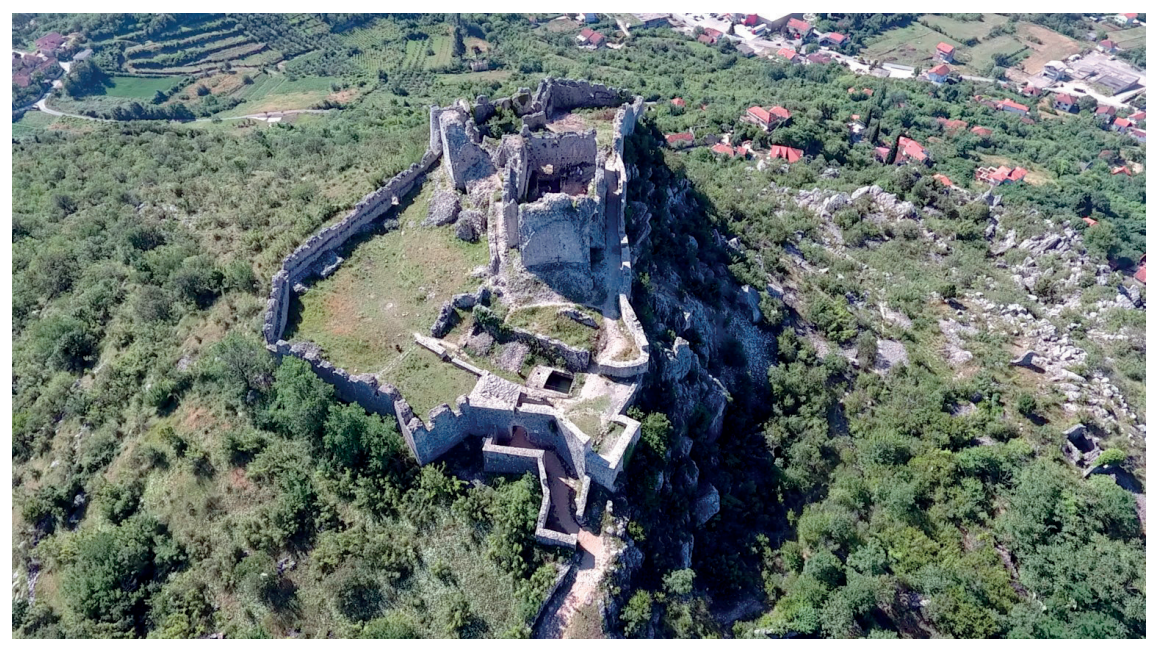

Slika 1. Zračni snimak lokaliteta Stari grad Ljubuški (foto: M. Rašić)

Prva istraživačka kampanja (2020. god.)

Druga istraživačka kampanja (2021. god.)

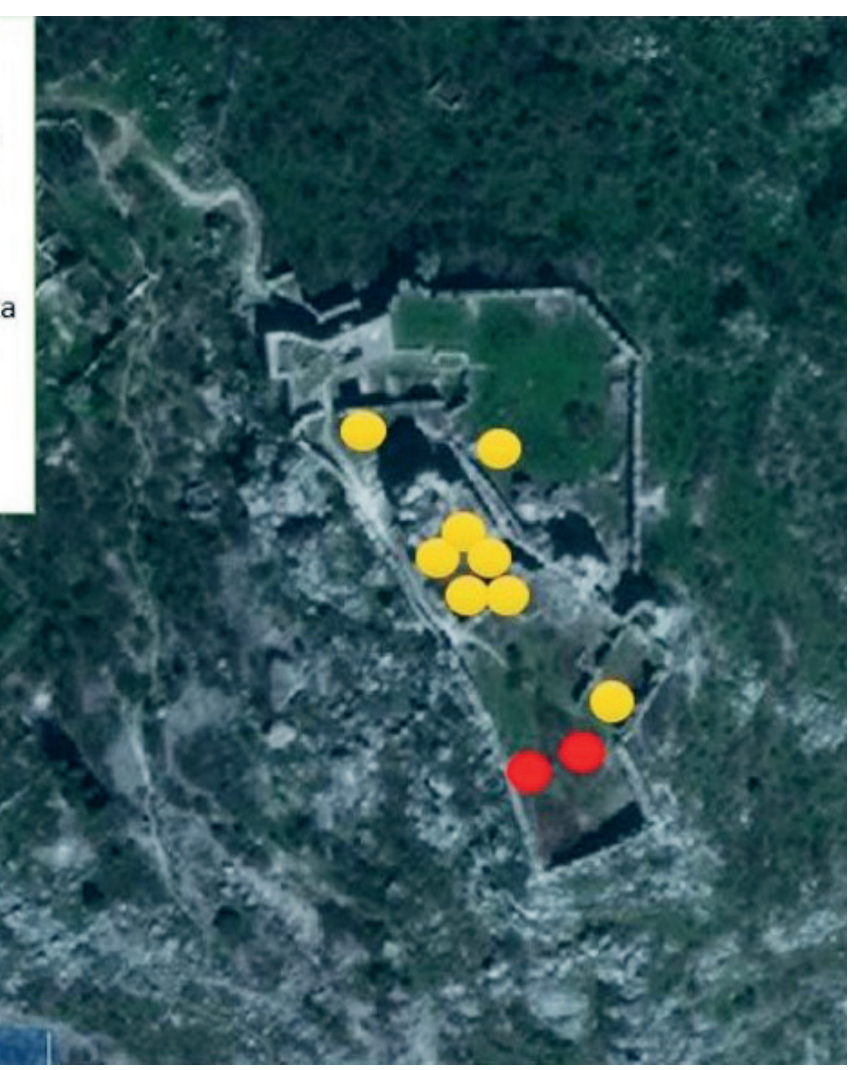

Slika 2. Pogled na lokacije arheoloških sondi (skica: N. Čuljak). 
Zasad najstariji poznati spomen Staroga grada u Ljubuškom datira iz godine $1435 .{ }^{4}$ Obrada toga lokaliteta u znanstvenoj se literaturi dosad zasnivala na pronađenoj arhivskoj građi te na osnovi zapažanja do kojih se došlo obilaskom lokaliteta. ${ }^{5}$ Pri tomu je vrlo važno istaknuti da je većina stručnih obrada starijega datuma. Nakon provedenih prvih arheoloških istraživanja možemo konstatirati da je zahvaljujući tomu današnja slika o Starom gradu Ljubuškom (i vizualno i sadržajno) ipak znatno šira, bolja i jasnija, no još uvijek slabo poznata i znatno manjkava. Radi dobivanja što cjelovitijih spoznaja istraživačke sonde koncipirali smo na različitim gradskim zonama, međutim, pri njihovu postavljanju bili smo prostorno znatno ograničeni, zbog urušenih blokova glavne kule i još nekih urušenih objekata unutar kojih nije bilo moguće provesti istraživanja. U nastavku ćemo ukratko predočiti rezultate istraživanja obiju arheoloških kampanja (sl. 2).

\section{Prva istraživačka kampanja}

Prvu kampanju arheoloških istraživanja lokaliteta Stari grad Ljubuški proveli smo tijekom lipnja 2020. godine. ${ }^{6}$ Istraživanja su planski organizirana u zoni s najugroženijim gradskim bedemima koji će

4 Dugo vremena bio je aktualan podatak o prvom spomenu Ljubuškoga koji datira u 1444. godinu (Desanka KovačEvić-KoJić, "O naselju Drijeva i njegovu položaju", u: Godišnjak društva istoričara Bosne i Hercegovine, XXI.-XXVII., Sarajevo, 1976., str. 33). Pretraživanjima izvora u Državnom arhivu u Dubrovniku D. Korać došla je do još starijega spomena koji datira u 1438. godinu (DIJana Korać, Vjera u Humskoj zemlji, Mostar, 2008., str. 51). Već iduće godine M. Sivrić novim je arhivskim podatcima pomaknuo datum prvoga spomena na 1435. godinu (Marijan Sivrić, "Dolazak franjevaca u Humsku zemlju i susjedno područje u srednjem vijeku", u: Hercegovina franciscana, god. V., br. 5, 2009., str. 71).

5 Navest ćemo neke: Hamdija Kreševljaković - Hamdija Kapidžić, "Stari hercegovački gradovi", u: Naše starine, II., Zavod za zaštitu spomenika kulture R BiH, Sarajevo, 1954., str. 13-14; Marko Vego, Naselja bosanske srednjovjekovne države, Svjetlost, Sarajevo, 1957., str. 71; HusRef ReDžıć, Srednjovjekovni gradovi u Bosni i Hercegovini, Sarajevo Publishing, Sarajevo, 2009., str. 143-144.

6 Istraživanja smo planirali provesti u nešto većem opsegu, s većim brojem sudionika, no, na žalost u to vrijeme je Hercegovina, kao i veći dio Europe, bila zahvaćena brojnim restriktivnim epidemiološkim mjerama kojima se pokušavalo reducirati širenje globalne pandemije uzrokovane korona virusom (COVID-19), tako da su na snazi bila i ograničenja kretanja i okupljanja većega broja ljudi i sl. 
biti prvi obuhvaćeni konzervatorsko-restauratorskim radovima. U prvoj kampanji to je bila zona tzv. južnoga gradskog obora. Tako smo se našli u vjerojatno najnepodesnijem dijelu lokaliteta za bilo kakva istraživanja. Naime, riječ je o terenu koji se iznimno strmo obrušava prema južnom bedemu, odnosno gdje postoji velika visinska razlika na relativno malom prostoru koju je vrlo teško savladati s obzirom na činjenicu da sve treba raditi ručno, uključujući i iznošenje iskopane zemlje i kamenja na viši dio lokaliteta do kojega se kasnije može pristupiti odgovarajućom mehanizacijom radi uklanjanja otkopane zemlje i kamenja. Drugi vrlo otežavajući čimbenik s kojim smo se susreli u toj zoni bio je ponovo posljedica navedene prve okolnosti (oštroga nagiba terena). Naime, stoljećima se sav obrušeni građevinski i ostali materijal kotrljao i sakupljao upravo u tom južnom (najnižem) dijelu te nas je dočekao višemetarski nanos građevinskoga šuta i arheološki materijal pomiješan s recentnim "nalazima". U južnom oboru otvorili smo dvije sonde koje smo označili kao sonde JO-1 i JO-2 (sl. 3 i 4).

$\mathrm{Na}$ žalost, tijekom istraživanja nismo uspjeli doći do intaktnog arheološkog sloja, jer ga na tom strmom dijelu terena uopće nije ni bilo, nego nam se kontinuirano javljao stratigrafski pomiješan materijal. Obje su sonde otvorene na lokacijama na kojima smo mogli detekti-

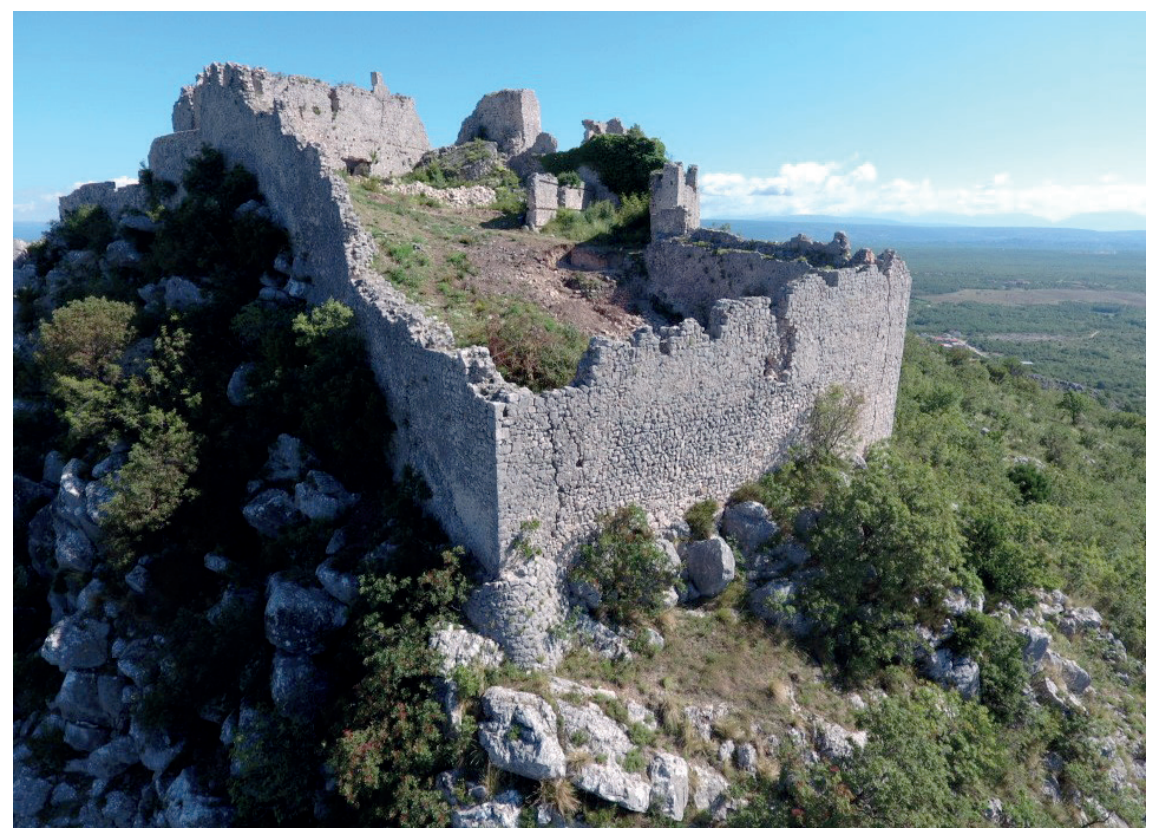

Slika 3. Pogled na južni obor (foto: M. Rašić) 


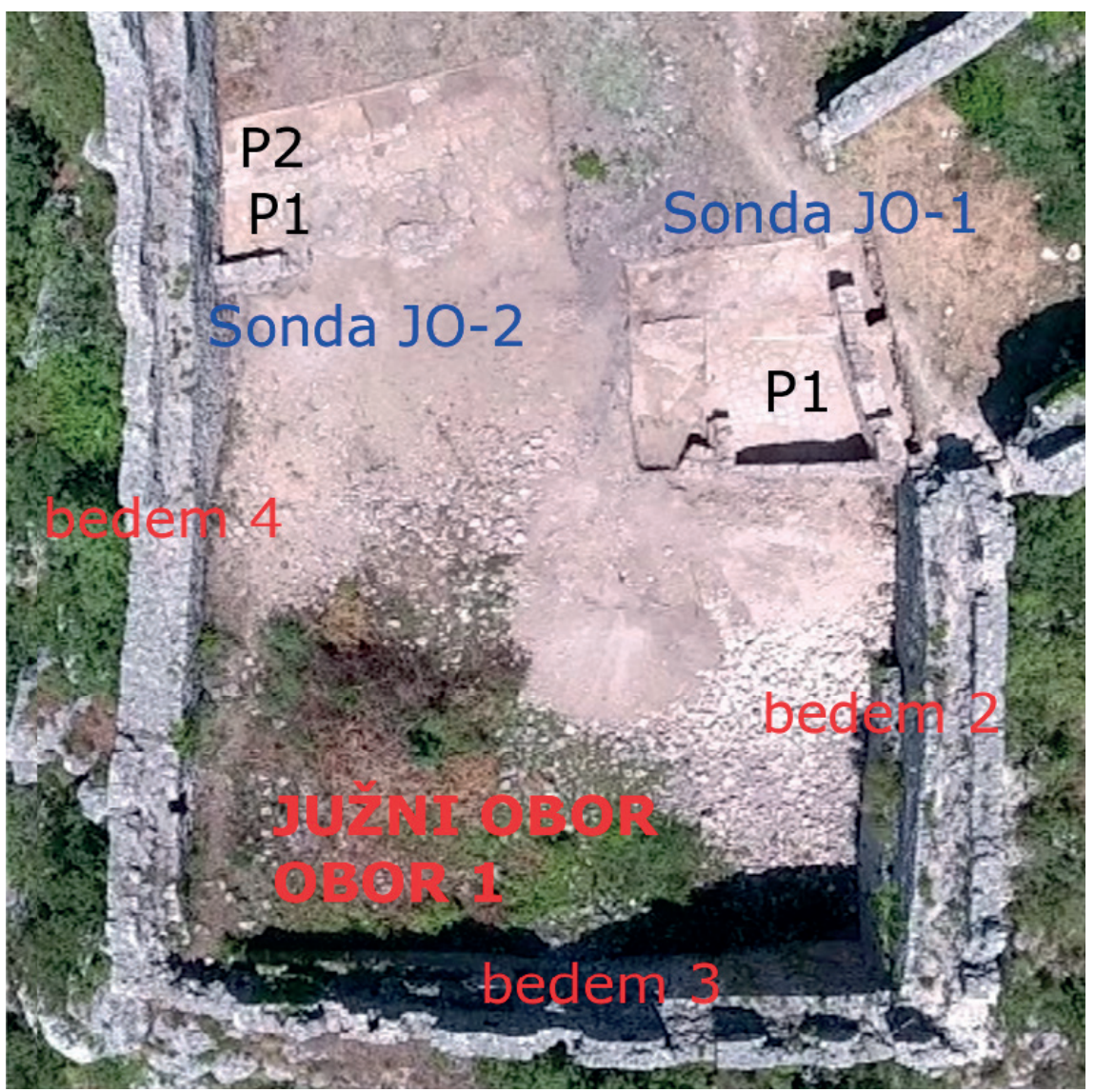

Slika 4. Položaj istražena prostora unutar južnog obora (skica: N. Čuljak)

rati naznake mogućih konstrukcija. Naslage šuta u nekim su zonama bile tanke, dok u drugim idu do dubine od čak $3 \mathrm{~m}$. U obje otvorene sonde došli smo do vrijednih otkrića prethodno u potpunosti nepoznate arhitekture.

\section{Sonda JO-1}

Prvu sondu JO-1 (sl. 5) veličine cca. 5 x 5 m otvorili smo u blizini Bedema 2 uz jedva vidljive naznake nekoga zida. Unutar sonde JO-1 otkrili smo i istražili jednu prostoriju koja ima dobro sačuvano kameno popločanje podnice od lijepo oblikovana i slagana kamenja.

U dokumentaciji smo je označili kao Prostorija 1. Bočno iznad nje, na višoj razini, utvrđeno je još jedno poravnanje terena s takvim po- 


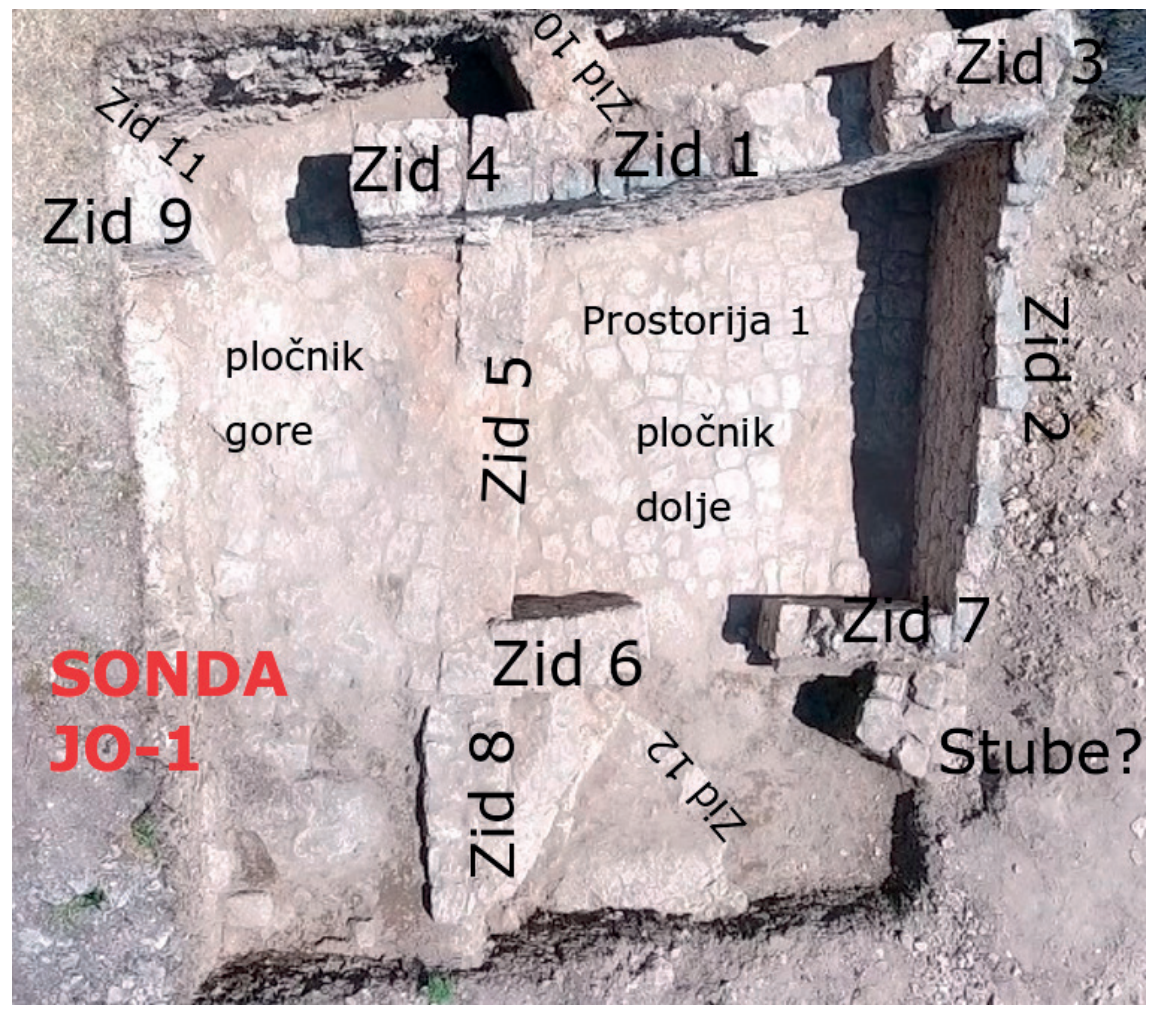

Slika 5. Sonda JO-1 (skica: N. Čuljak)

pločanjem, no s prilično lošijim, isprekidanim uklapanjem na kamen živac. Unutar te sonde pronađeno je mnogo materijala koji datira iz vremena kasnoga srednjeg vijeka i ranoga novog vijeka, no na žalost, u svim otkopnim slojevima naišli smo na stratigrafski pomiješan materijal, tako da nismo imali očekivani intaktni arheološki sloj. Nalaza iz vremena XIX. i XX. stoljeća bilo je malo, a oni se uglavnom odnose na čahure, puščana zrna i komade staklenih boca.

\section{Sonda JO-2}

Sonda JO-2 (sl. 6) veličine cca. 8 x 4 m postavljena je uz vidljivi komadić zida koji se pod oštrim kutom spaja na Bedem 4. Ondje su također utvrđeni manji dijelovi zidova koji naslućuju nove prostorije na prostoru južnog obora.

Sonda je postavljena uz Bedem 4 na koji se pod određenim kutovima naslanjaju dva zida. Označili smo ih kao Zid 1 (južniji) i Zid 


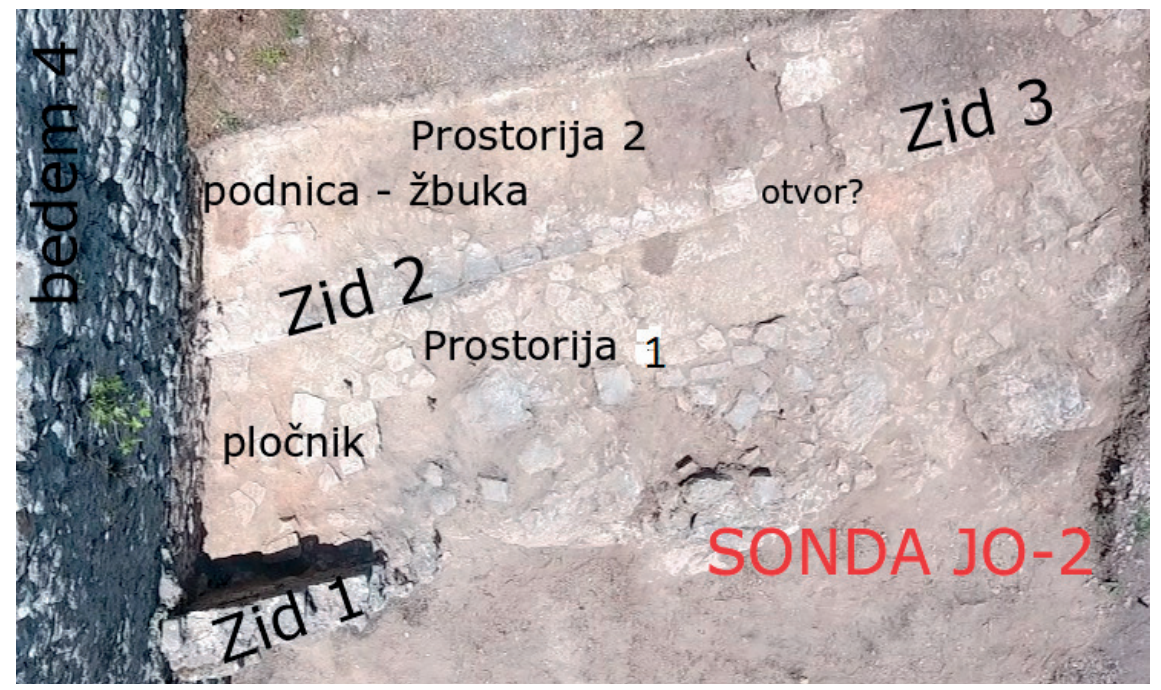

Slika 6. Sonda JO-2 (skica: N. Čuljak)

2 (sjeverniji), koji se, kako se čini, prekida nekim uskim otvorom i nastavlja u vidu Zida 3. Zidovi 1 i 2, zbog naravi terena i nepoznate funkcije, ne pružaju se posve paralelno. Zid 1 je orijentiran u smjeru S - J, a Zid 2 odstupa od toga smjera te se nalazi u smjeru SI - JZ. Između ta dva zida unutarnje granične točke uz bedem udaljene su $180 \mathrm{~cm}$. Između Zidova 1 i 2 pronađen je sloj šuta, a zanimljivost su svakako nalazi niza potkova za obuću i čavala, što možda ukazuje na funkciju toga manjeg nepravilna prostora. ${ }^{7}$ Ispod nevelika sloja šuta čija debljina varira u različitim dijelovima, otkriveno je tzv. fino popločanje podnice, slično kao u Prostoriji 1 u Sondi JO-1, no na tom je mjestu podnica mnogo lošije sačuvana. Mogući razlog za to je i loše utemeljenje okolnih zidova $i$ isprekidanost izbojcima matične stijene na kojoj su uklopljeni kako zidovi, tako i podnica. Sjevernije od Zida 2 primijetili smo žbukanu podnicu, što navodi na to da se cijeli takav prostor širi i dalje, no s obzirom na to da je taj dio izlazio iz okvira sonde koju smo do kraja kampanje mogli i morali dovršiti do kraja, nismo ga iskopavali. Nalazi u navedenu dijelu iskopa bili su uglavnom metalni, željezni dijelovi spomenute potkove i kovani četverobridni T-čavli te keramika.

7 S obzirom na to da je riječ o preliminarnim rezultatima istraživanja, u ovom radu donosimo samo lokacije i skice istraženih sondi, a u idućem radu slijedi objava fotografija reprezentativna materijala sa svom popratnom relevantnom znanstvenom literaturom. 
Nina Čuljak - Ante Uglešić - Preliminarno izvješće o arheološkim istraživanjima...

\section{Druga istraživačka kampanja}

Druga istraživačka kampanja provedena je tijekom travnja 2021. godine. Prioritet te kampanje bilo je istraživanje obora uz glavnu kulu, tzv. Hercegušu (sl. 7), jer će se taj dio lokaliteta konzervirati i restaurirati tako da vjerojatno ne će više biti mogućnosti za nova istraživanja na tom dijelu obora. Ostale su sonde otvorene na sljedećim lokacijama: Sonda P-1 otvorena je u produžetku prošlogodišnje sonde JO-1, a njezin je cilj bio utvrditi daljnje prostiranje zidova koji su se tamo pojavili na rubnim prostorima (sl. 12-13). S obzirom na to da se tamo pojavio također novi zid i stratigrafska situacija se usložila, kasnije je za taj dio uvedena i nova sonda P-4. Sonda P-2 otvorena je s vanjske strane ulaza u obor "Herceguše". U istraživanja je tako bio uključen i ulazni dio obora koji se istražio i s vanjske strane te tako omogućio i nesmetan ulaz u taj prostor. Sonda P-3 (sl. 2) otvorena je u prostoru između velike gradske cisterne i kule "Herceguše", s ciljem definiranja izgradnje, odnosno vremena korištenja toga naizgled definirana prostora. Naposljetku, jednu probnu sondu otvorili smo i na prostoru tzv. Velikog obora za koji se pretpostavlja (s obzirom na evidentno najkasnije dozidane bedeme) da je korišten kao gradski prostor tek u osmanskom periodu.

\section{Sonde unutar obora kule "Herceguše" (OHA-1, OHA-2, OHB-1 i OHB-2) i sonda kod ulaza u obor (P-2)}

Tu smo zonu podijelili na četiri sonde, nastojeći pritom ne komplicirati uklapanjem kvadratne mreže u zoni koja je već podijeljena zidovima te smo se držali već tako postavljenih orijentira. Također, radi što manjega destruktivnog djelovanja, nismo željeli probijati sačuvane dijelove gornje podnice tamo gdje je dobro sačuvana i gdje su u nju ugrađene baze. Taj smo prostor tako imenovali već prema njegovoj postojećoj podjeli na sonde: OHA-1, OHA-2, OHB-1 i OHB-2 (sl. 7). Započeli smo iskopavanje od sonde OHA-1, unutar koje smo uočili postojanje velika sloja građevinskoga šuta s pomiješanim kasnosrednjovjekovnim i novovjekovnim materijalom. Ustanovili smo i postojanje gornje i donje podnice od solidno nabijene žbuke, ali sačuvane samo u krajevima prostorije, tj. obje podnice u toj sondi uglavnom su bile probijene. Za gornju podnicu jasno je da visinski korespondira sa sačuvanim pragom na ulasku u taj prostor, a tada je ulaz u obor već bio sužen dogradnjom još jednoga komada zida (sl. 10). Donja podnica je očito bila na samom kamenu živcu (matičnoj stijeni) koji je neravan i gdje je vidljivo da je taj dio bio popunjen i izniveliran, a 
OBOR UZ KULU "HERCEGUŠU"

nakon arheol. istraživanja 2020. i 2021. god.

radna skica: $\mathrm{N}$. Čuljak

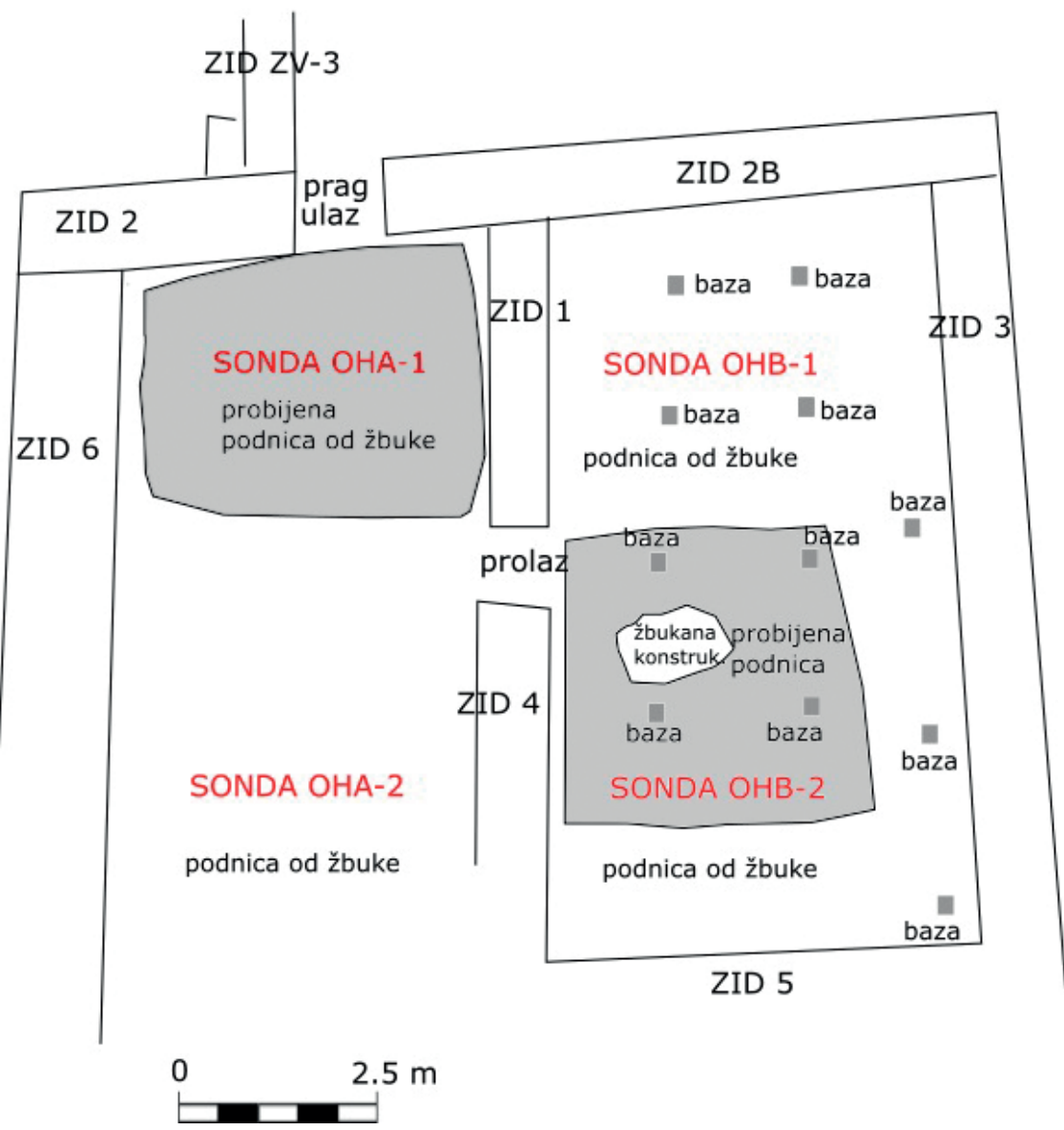

Slika 7. Prikaz sondi unutar obora uz kulu "Hercegušu" (skica: N. Čuljak)

potom ožbukan. Upravo su nam u tim donjim stratigrafskim jedinicama bili sačuvani intaktni kasnosrednjovjekovni arheološki slojevi.

Unutar sondi OHB-1 i OHB-2 uklonjen je sloj šuta, slično kao i u sondi OHA-1 te se došlo do gornje podnice koja je u sondi OHB-1 posve dobro sačuvana. Na njoj su također bile in situ sačuvane kamene baze (sl. 8) od neke vjerojatno podne ili stropne drvene konstrukcije, a koje su zapravo ukopane i ugrađene u žbuku gornje podnice. Za neke od njih pretpostavljamo da je riječ o kasnosrednjovjekovnim 


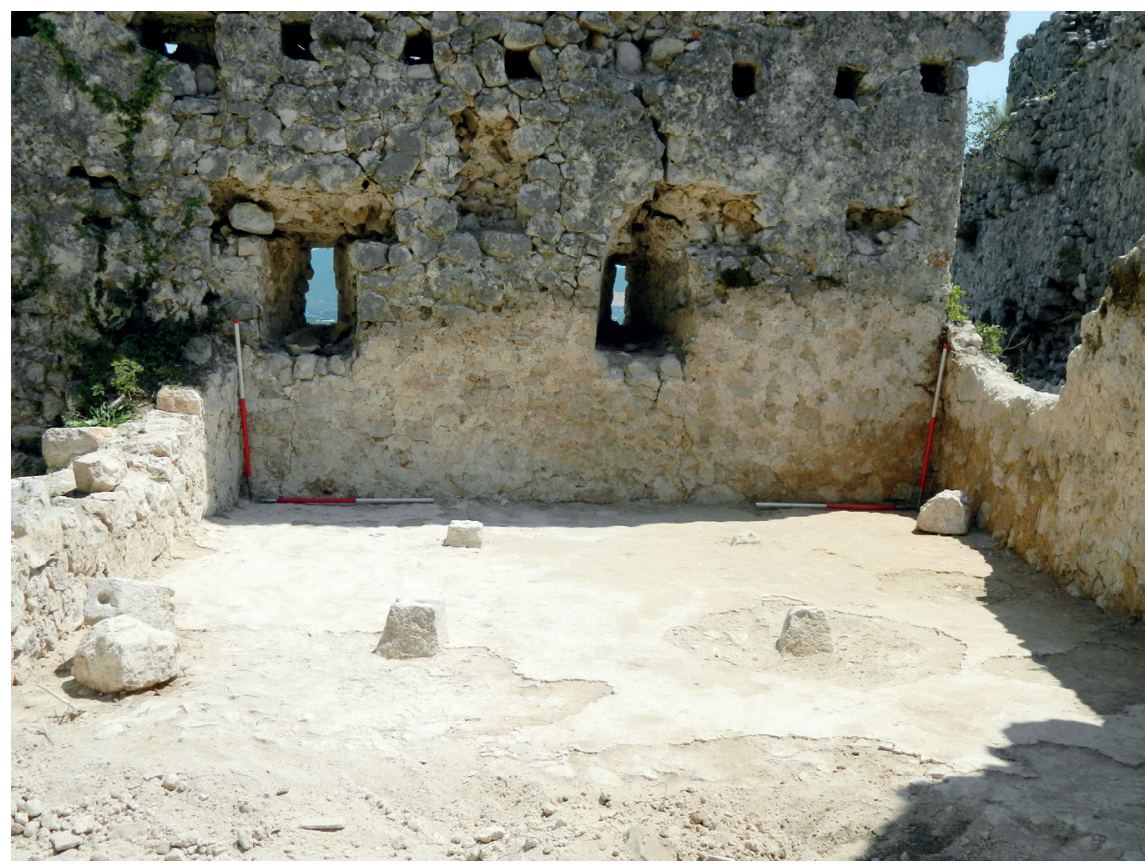

Slika 8. Pogled na očišćenu žbukanu podnicu unutar Sonde OHB-1 $s$ ugrađenim kamenim bazama (foto: $\mathrm{E}$. Vučić)

neukrašenim kapitelima koji su početkom novoga vijeka sekundarno upotrijebljeni kao naopačke okrenute baze. Podnicu smo očistili i dokumentirali te u tom dijelu nismo dalje nastavili iskop.

Unutar sonde OHB-2 također smo ispod velika sloja šuta s pomiješanim materijalom naišli na gornju podnicu koja je bila gotovo četvrtasto probijena te smo nastavili iskopavati u tom probijenom dijelu. Pri tomu smo pronašli četiri žbukana ležišta od kamenih baza, koje su također ležale u njihovoj neposrednoj blizini. Pronašli smo i ovalnu ožbukanu konstrukciju (sl. 9), nekoliko novih stratigrafskih jedinica iz kasnoga srednjeg vijeka, ali sve je to ponovo bilo u tanku sloju između kamena živca (matične stijene) i neposredno nad njim, odnosno ispod razine podnice. $U$ toj smo sondi otkrili i prethodno nepoznati Zid 5.

Temeljem provedenih istraživanja utvrdili smo da nalazi iz prostora obora kule "Herceguše" ne ukazuju na postojanje nekih starijih faza te početak njezina korištenja smještaju u kasni srednji vijek. Također, iz prvoga pregleda materijala imamo indicija da taj prostor nije bio dugotrajno korišten u rezidencijalne stambene namjene. Količina 


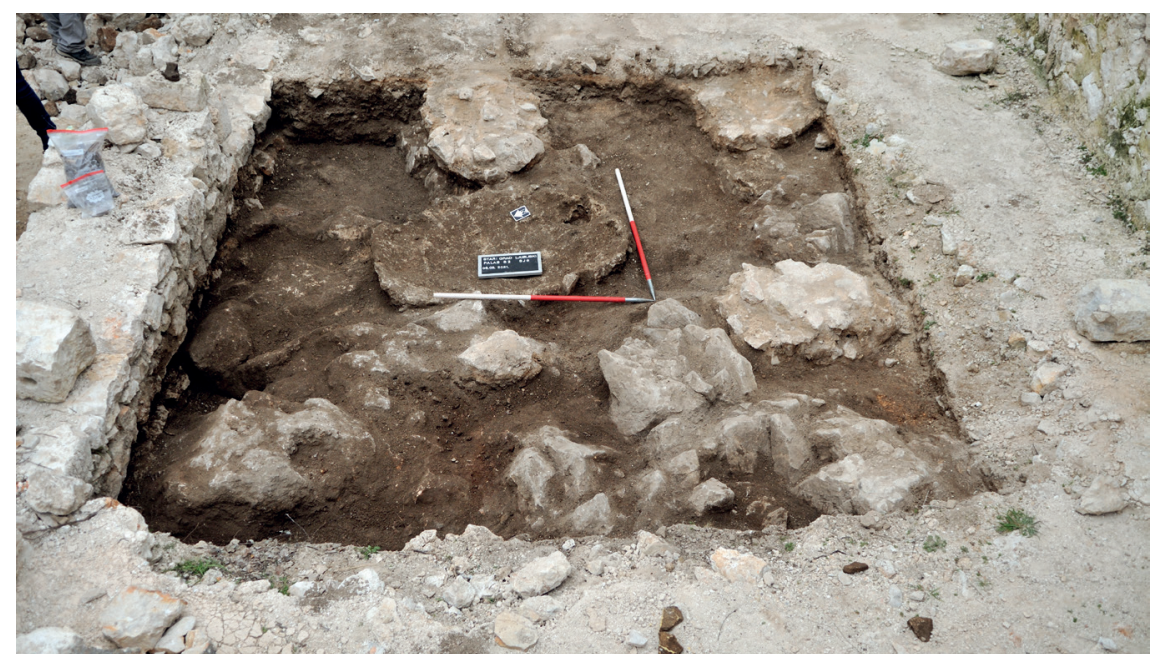

Slika 9. Pogled na Sondu B-2 i ovalnu ožbukanu konstrukciju (foto: M. Rašić)

ulomaka luksuzne stolne glazirane keramike i ulomaka staklenoga posuđa iznimno je mala. Daleko je više ulomaka domaće kuhinjske keramike zastupljene kroz nekoliko tipova, premda ona još nije temeljito obrađena i za nju vrijedi konstatacija da nije brojna. Među pronađenim pokretnim arheološkim nalazima najviše su zastupljeni ulomci građevinskoga materijala, dijelova crijepova, a također su relativno brojni nalazi različitih željeznih predmeta, odnosno masivnih četverobridnih kovanih čavala i predmeta nepoznate namjene. U kasnosrednjovjekovnom sloju bilo je i ljuštura morskih školjki (dagnje i priljepci), koji nam govore o nekim prehrambenim navikama tadašnjih vlasnika. O prehrambenim navikama također svjedoče ostatci životinjskih kostiju koji uglavnom pripadaju stoci sitnoga zuba, odnosno ovcama i kozama. S vanjske strane ulaza u obor "Herceguše" omanjom je sondom definiran ulazni dio pri čemu se došlo do otkrića novoga zida koji se pruža okomito na ulaz, a s njegove bočne strane nalazi se neka dozidana konstrukcija ili široka stepenica. Nalazi iz te zone bili su isključivo šut i stratigrafski pomiješan arheološki materijal.

\section{Sonda P-3}

Sonda P-3 (sl. 11) postavljena je u prostoriji koja je djelovala kompaktno, a za koju se ispostavilo da je riječ o prostoriji recentna nastanka koja ima i drugačiju podnicu od ostalih pronađenih, rađenu od zbi- 
Nina Čuljak - Ante Uglešić - Preliminarno izvješće o arheološkim istraživanjima...

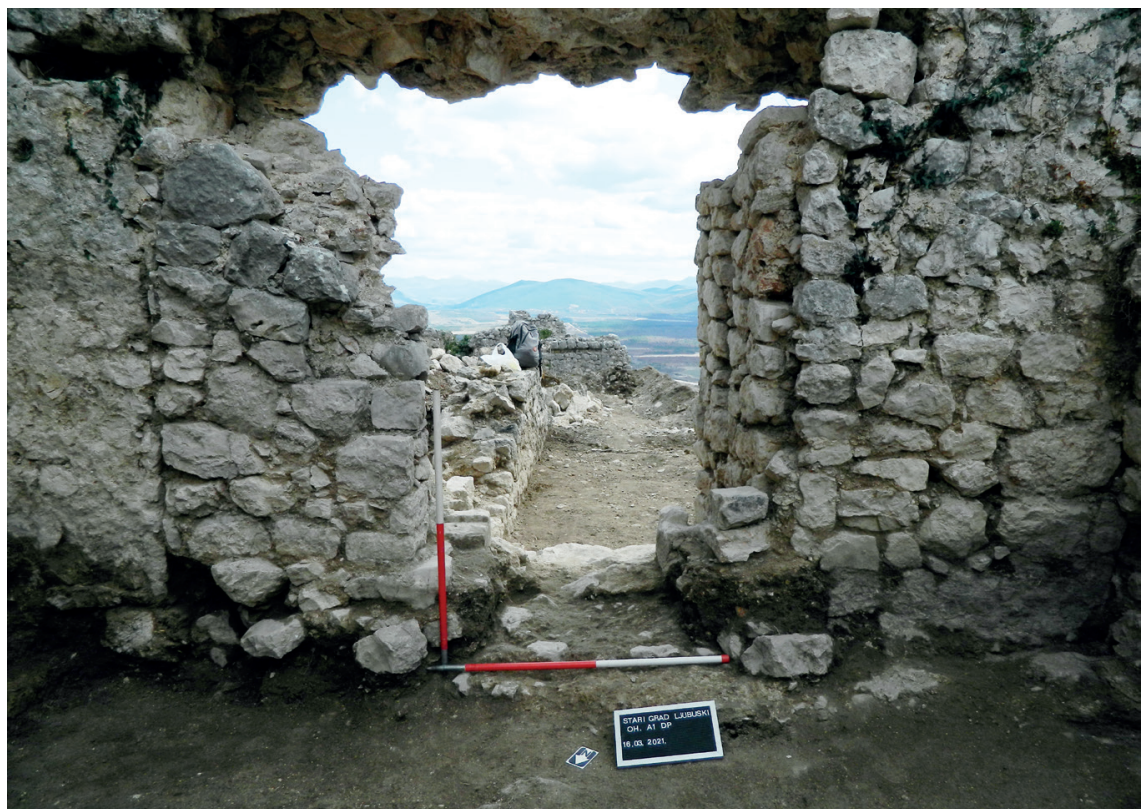

Slika 10. Pogled na dio donje podnice i iznad/iza ostatak sužena ulaza s utorima iz vremena gornje podnice (foto: $N$. Čuljak)

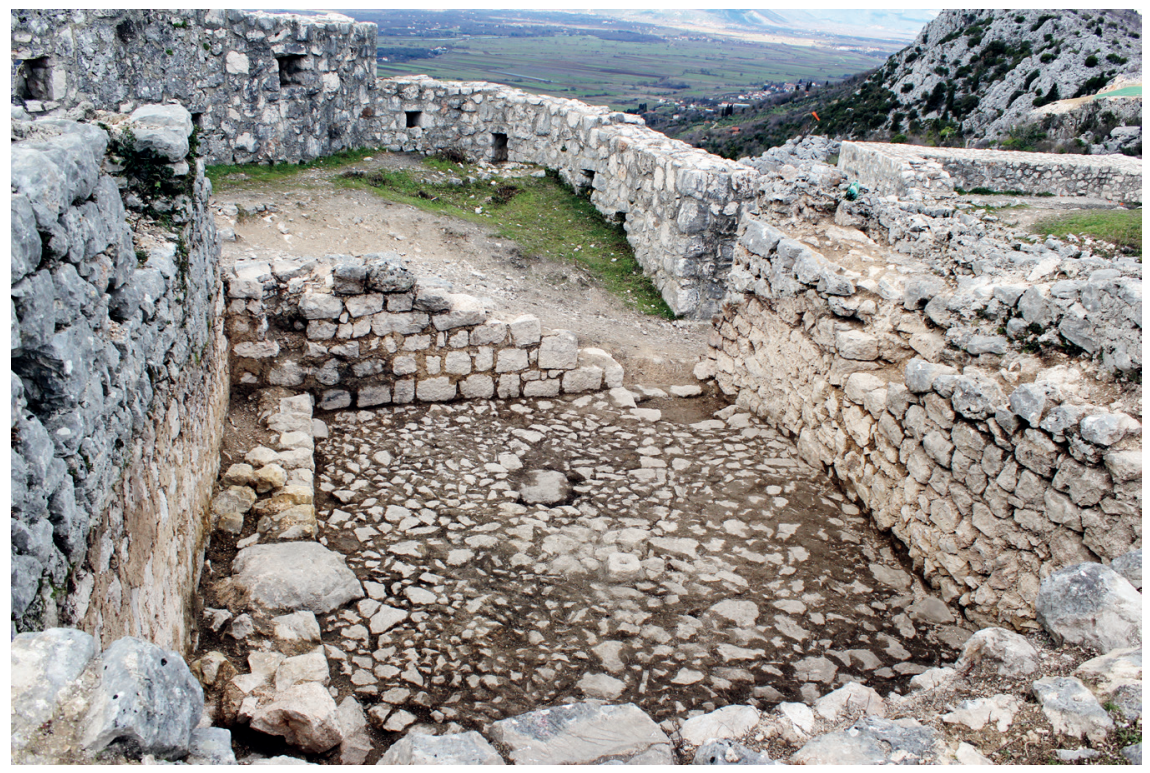

Slika 11. Pogled na situaciju unutar istražene Sonde P-3 (foto: A. Uglešić) 
jenoga amorfnoga kamenja. Nalazi iz te sonde ukazuju da je riječ o prostoriji koja je očito iz vojnih razloga bila dozidana i korištena tek u XIX. stoljeću, moguće kao prostor za smještaj straže. Kada detaljnije analiziramo nalaze iz te prostorije, sigurno je da će biti i novih interpretacija u razumijevanju prestanka korištenja cijeloga lokaliteta, odnosno njegove preinake i naknadnoga korištenja za vojne potrebe. Najzanimljiviji nalazi iz te prostorije dijelovi su omanjega brončanog topa te djelomice sačuvan mač u koricama. Vrijedni spomena su i neki sitni nalazi poput vinskih staklenih boca s udubljenim dnom, komadić lule s vojničkim likom - mogući mladenački prikaz cara Franje Josipa I. (1848.-1916.), brončana kovanica (Kreutzer iz 1859.), puščane čahure s utisnutom godinom 1872. i dr.

\section{Sonde P-1 i P-4}

$\mathrm{U}$ produžetku prošlogodišnje sonde u smjeru sjeveroistoka (sl. 2) u južnom oboru (JO-1) otvorili smo novu sondu P-1 koju smo naknadnim otkrićem jednoga zida koji je u gornjem dijelu građen od sedre (Zid 10) i proteže se paralelno s postojećim bedemom, podijelili na prostor P-4 (s južne strane toga zida). U tom dijelu, u Bedemu 1, otkrili smo uzidani kamin iz novovjekovnog razdoblja (sl. 12 i 13). Najveće otkriće u tom sektoru, a ujedno najvažnije za cijela istraživanja bili su zidovi pronađeni ispod spomenuta zida u gornjem dijelu građena od sedre. Prvi zid (Zid 13) proteže se okomito u odnosu na bedem, a građen je u posve drugačijoj tehnici od ostalih na cijelom lokalitetu, relativno pravilnim klesancima, odnosno načinom karakterističnim za razdoblje antike. Ispod njega, uzduž cijelog otkrivenog dijela, nalazi se njegov podzid, odnosno temeljna stopa (ili posve novi zid) $s$ vidljivim fragmentima ugrađenih tegula u jednom dijelu (označen kao Zid 14). S obzirom na skučenost sonde i gustoću pronađenih zidova, u ovoj fazi istraživanja nije moglo na tom dijelu širiti i podrobnije proučiti te donje strukture. Time smo zasad ostali uskraćeni saznanja u kakvu su točno suodnosu bili ti zidovi. Izglednom se čini pretpostavka da su to zidovi iz dviju različitih faza, no takva razmišljanja treba konkretno dodatno provjeriti, a to nije moguće bez dodatnih arheoloških istraživanja. Osim opisanih zidova, među vrlo važne i zanimljive nalaze pripadaju ulomci niza keramičkih posuda pronađeni uz njihove temelje, koji se po svojim karakteristikama mogu datirati u ranobizantsko razdoblje (VI.-VII. stoljeće).

U cjelini gledajući, nalazima iz Sonde P-4 utvrđeno je da je srednjovjekovni Stari grad Ljubuški izgrađen na mjestu gdje je već u ka- 


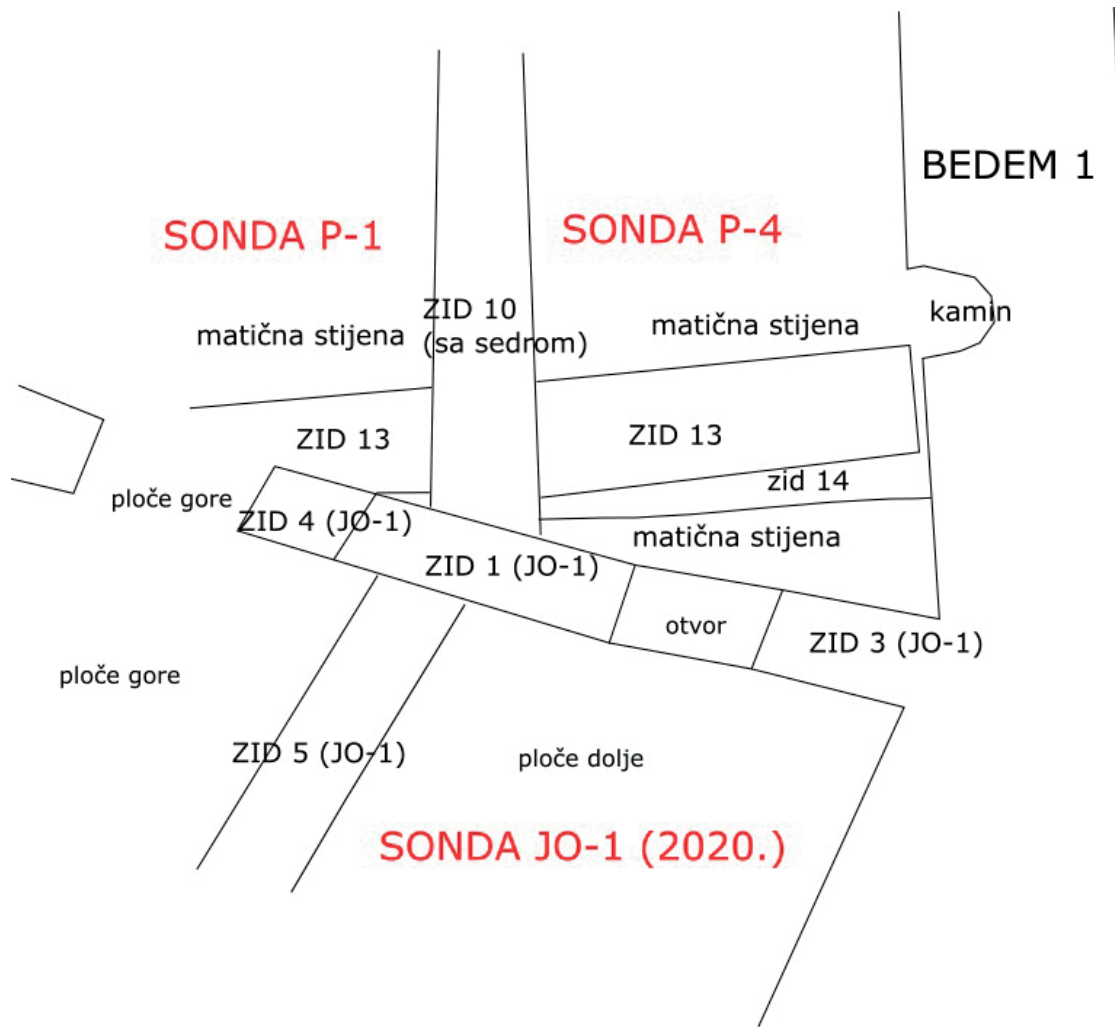

Slika 12. Zidovi unutar Sonde P-1 i P-4 (skica: N. Čuljak)

snoantičko doba postojala neka građevina. Zbog vrlo kompliciranih struktura u toj zoni, po svoj prilici nikada ne ćemo moći utvrditi cijeli prostor njezina rasprostiranja, odnosno tlocrtnu situaciju, no može se pretpostaviti da bi se trebalo raditi o utvrdi (castrum) ili osmatračnici manjih dimenzija koju su preslojili zidovi srednjovjekovnoga grada.

\section{Sonda VO-1}

Jednu probnu sondu otvorili smo unutar tzv. velikog obora (sl. 14) kojeg opasuju bedemi podignuti u osmanskom periodu. Cilj te sonde bio je definiranje svrhe i vremena korištenja tog dijela gradskog prostora. Sondu smo označili kao VO-1. U njoj smo ispod humusnoga sloja došli do jednoga zidića za koji se ispostavilo da je prilično plitak te da leži na starijem sloju u kojem smo ustanovili niz stratigrafskih jedinica za koje se preliminarno može reći da su mahom iz kasnoga srednjeg vijeka (s neznatnim miješanjem drugoga materijala u po- 


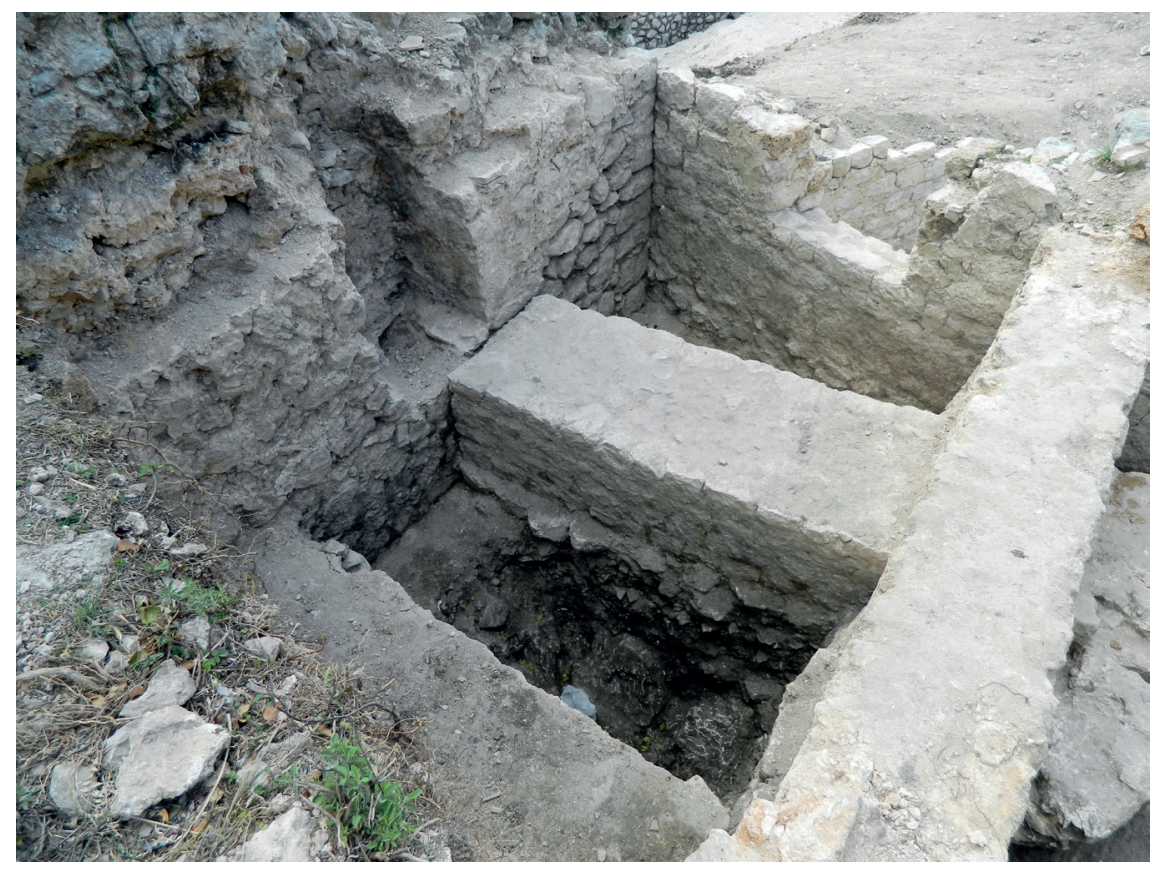

Slika 13. Sonda P-4 nakon istraživanja (foto: N. Čuljak)

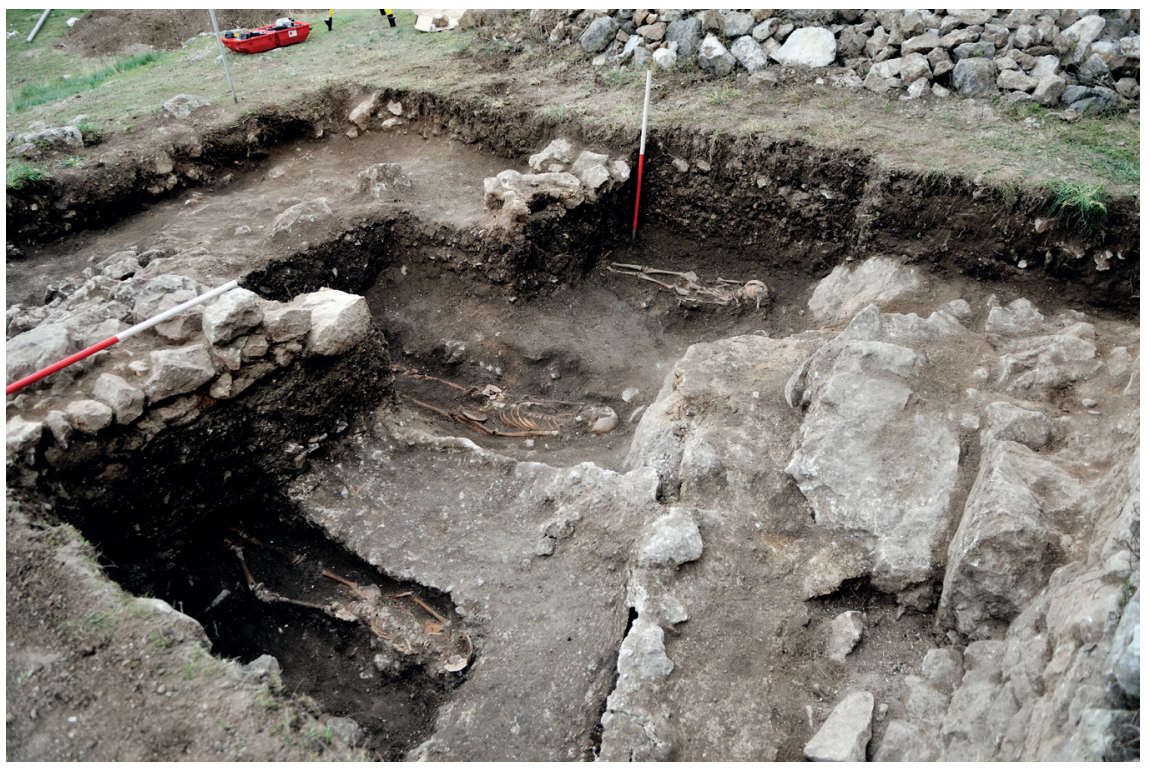

Slika 14. Pogled na grobove unutar Sonde VO-1 (foto: M. Rašić) 
Nina Čuljak - Ante Uglešić - Preliminarno izvješće o arheološkim istraživanjima...

vršinskim slojevima). Ispod humusnoga sloja pronađene su naslage vapna koje upućuju da je to bio prostor gdje se pripremao i miješao malter za gradnju. Ispod sloja vapnene žbuke te ispod recentnoga zida pojavili su se grobovi. Riječ je o tri ukopa u odvojenim rakama bez grobne arhitekture, jedne odrasle i dvije mlađe osobe orijentiranih u smjeru jugozapad (glava) - sjeveroistok. U zapuni grobova pronađeni su ulomci grube keramike i životinjskih kostiju, no za njih je izgledno da nisu u vezi s ukopima, nego rezultat zapune dostupnom zemljom iz okolnih kulturnih slojeva.

\section{Zaključak}

Nakon dvije kampanje arheoloških istraživanja provedenih na lokalitetu Stari grad Ljubuški možemo konstatirati da smo došli do niza novih spoznaja o tom hercegovačkom kulturno-povijesnom spomeniku koji je prethodio nastanku današnjega grada. Jednako tako mogućnost daljnje valorizacije rezultata tih istraživanja i pronađene arheološke građe zasigurno će iznjedriti za znanost još niz novih i korisnih podataka. Istraživanja provedena 2020. godine u južnom oboru pokazala su da prostor koji prilično oštro pada prema jugu i iz kojeg izranjanju veliki dijelovi matične stijene (te se činilo da nema kulturnoga sloja), zapravo krije cijeli niz građevinskih konstrukcija. Cijelokupni taj prostor bio je očito u potpunosti iskorišten na način da su se graditelji doslovce terasasto usijecali u kosinu južnoga gradskog obora, duž bedema, i aktivno su koristili matičnu stijenu za sve graditeljske zahvate u toj zoni. Središnju komunikaciju (stepenice) nismo ustanovili, no ona je ondje svakako morala postojati. $U$ obje sonde, na tri odvojene razine, ustanovili smo lijepo osmišljena popločanja, što ukazuje na to da se tom prostoru ipak pridavao značaj. O tomu svjedoče nalazi fine domaće keramike, a osobito uvozne glazirane keramike i stakla, koji upućuju na jednu višu stambenu iskorištenost prostora sonde JO-1 ili neposrednu blizinu stambene zone s koje potječe i materijal pronađen obrušen u šutu.

Rezultati druge istraživačke kampanje pružili su nam još više novih podataka. Na prvom mjestu spominjemo upoznavanje situacije unutar obora kule "Herceguše" za koji se pretpostavljalo da skriva možda i starije slojeve. Istraživanja su pokazala da su najstariji slojevi utemeljeni na matičnoj stijeni iz vremena kasnoga srednjeg vijeka, odnosno da prostor obora uz "Hercegušu" datira iz vremena kasnoga srednjeg vijeka te da je nešto kasnije imao određene arhitektonske preinake. Primjer takvih zahvata između ostalog je sužavanje ulaza 
u taj prostor kao i ugradnja kamenih baza u gornju podnicu i dr. Podatke za kulu nismo mogli ustanoviti, jer je njezin cjelokupni prostor prekriven obrušenim blokovima zidova te je sonde tamo bilo nemoguće postaviti. Znanstvena obrada pronađene arheološke građe tek slijedi, no usprkos tomu možemo preliminarno konstatirati da postoji mogućnost izostanka očekivana sloja koji bi ukazivao na stambenu iskorištenost toga prostora u osmanskom periodu. Kako se sada čini izglednim, taj je prostor u navedenu vremenu bio korišten samo u vojne svrhe, ne i za stambene. Treba istaknuti da također za predosmanski period nemamo previše dokaza o aktivnom korištenju u stambene svrhe toga dijela utvrde. Popratnog sitnog arheološkog materijala tamo je pronađeno, no ne u tolikoj količini u kolikoj bi to bilo logično očekivati. Nalazi koji govore o životu toga prostora u kasnom srednjem vijeku svedeni su na ulomke glazirane keramike, fine domaće keramike, naprstaka za šivanje, ljuštura morskih školjki i životinjskih kostiju itd.

Istražena Sonda P-3 dala je zanimljive nalaze koji najvećim dijelom potječu iz XIX. stoljeća, a daljnjom njihovom interpretacijom zasigurno će se bolje moći razumjeti način daljnjeg korištenja grada u vojne svrhe.

U Sondi VO-1 otkrili smo tri groba i pokretne arheološke nalaze iz više stratigrafskih jedinica, među kojima spominjemo osobito lijepe ulomke domaće i uvozne keramike te različite metalne predmete. Svim tim nalazima slijedi dodatna stručna i znanstvena obrada.

Naposljetku, Sonde P-1 i P-4 iznjedrile su nam niz novih nalaza, među kojima i najvažnije otkriće - najstarije zidove izgrađene na kamenu živcu (matičnoj stijeni) i ulomke različitih keramičkih posuda koji se mogu datirati u ranobizantsko razdoblje (VI. i VII. stoljeće). To posljednje otkriće svakako je bilo osobito zanimljivo i važno, jer nam je potvrdilo postojanje kasnoantičke građevine na lokalitetu Stari grad Ljubuški, a ujedno je ostavilo mogućnost pretpostavke o postojanju još starijeg objekta na tom prostoru. Time je ujedno utvrđeno da je kasnosrednjovjekovni grad-utvrda jednim dijelom podignut na mjestu starije utvrde ili kule- osmatračnice.

Ovdje su izneseni, kako je to već iz naslova članka vidljivo, samo preliminarni rezultati istraživanja. Slijede mnogo detaljnija proučavanja otkopana materijala i arhitekture, no već ovim prikazanim rezultatima polako popunjavamo prazne stranice prošlosti toga znamenita hercegovačkog spomenika čije je retke već odavno velikim dijelom neumoljivo izbrisalo vrijeme. 